\title{
Verbaliserade och praktiserade språknormer inom Svenska för invandrare
}

\author{
Annika Norlund Shaswar
}

\section{Inledning}

Sverige kan beskrivas som ett flerspråkigt land, präglat av globalisering och mobilitet med många utbildningskontexter som är språkligt heterogena $\mathrm{i}$ den bemärkelsen att eleverna har kunskaper i fler språk än undervisningsspråket svenska. En av dessa utbildningskontexter är Svenska för invandrare, sfi. Sfi erbjuder utbildning i svenska som andraspråk för vuxna som är bosatta $\mathrm{i}$ Sverige (Skolverket 2019), och enligt kursplanen (Skolverket 2019) är syftet med utbildningen att eleverna ska utveckla ett funktionellt andraspråk, det vill säga svenska.

För sfi-elever som ännu inte är funktionellt litterata ska utbildningen även tillhandahålla grundläggande läs- och skrivundervisning. Detta är en självständig del som kan integreras med kurserna och kan enligt kursplanen "ske på elevens modersmål eller ett annat språk som eleven behärskar." (Skolverket 2019: 4) Dock sker i praktiken den grundläggande läs- och skrivundervisningen ofta på svenska, bland annat eftersom undervisning på annat språk inte är ett eftertryckligt krav i styrdokumenten. Lärarna som undervisar i grundläggande läs- och skrivundervisning står alltså inför utmaningen att stödja elever så att de kan utveckla grundläggande litteracitet på svenska, vilket för eleverna är ett andraspråk där de befinner sig på nybörjarnivå.

Samtidigt som sfi-lärare står inför det ovan beskrivna utmanande didaktiska uppdraget är det en lärargrupp som har litet stöd för sitt undervisningsuppdrag i lärarutbildning, eftersom lärarutbildning särskilt inriktad mot sfi saknas, och kurser i svenska som andraspråk inom lärarutbildning endast $\mathrm{i}$ liten utsträckning är inriktade mot vuxenundervisning generellt (Fejes 2019) eller mot grundläggande läs- och skrivutveckling hos vuxna specifikt. Till sin hjälp har lärarna inte heller didaktiskt inriktad forskning om grundläggande läs- och skrivundervisning för vuxna andraspråksinlärare eftersom forskning om sfi-undervisning (Lundgren 2005; Gustavsson 2007; Franker 2011) endast i viss utsträckning har fokuserat på didaktiska aspekter (se Lundgren \& Rosén 2017 för en översikt).

När sfi-lärare ställs inför den svåra uppgiften att utföra grundläggande läsoch skrivundervisning på ett undervisningsspråk som är nytt för eleverna, är det viktigt att de får stöd $i$ att utveckla pedagogiska praktiker som tar tillvara de språkliga erfarenheter och resurser som eleverna har med sig till klassrummet, exempelvis genom att tillämpa transspråkande (García 2009; García \& Li Wei 2014), så att de får bättre förutsättningar för språkutveckling. 
Dock finns ett hinder i vägen för sfi-lärarnas möjlighet att utveckla en sådan pedagogik i form av den enspråkigt svenska språknormen som dominerar svenska utbildningskontexter. Denna enspråkiga språknorm utgörs av uttalade och outtalade regler enligt vilka enbart ett språk, svenska, ska användas (Hyltenstam \& Milani 2012; Rosén 2017; Wedin, Rosén \& Hennius 2018). Denna norm innebär ett hinder för sfi-lärare eftersom den är förknippad med ett bristperspektiv på elevernas språkliga kunskaper, det vill säga att man betonar brister $\mathrm{i}$ behärskning av svenska mer än deras övriga språkliga kompetens (Franker 2011; Norlund Shaswar 2014). Vidare bidrar den enspråkiga normen till ett osynliggörande av elevernas kunskaper i andra språk än svenska och försvårar för lärarna att utforma transspråkande undervisningsformer som utgår från att flerspråkighet är en resurs (García 2009). En sfi-lärare kan vackla mellan den starka enspråkiga normen att enbart svenska ska användas i klassrummet och en uppfattning om att en flerspråkig norm skulle vara till fördel till eleverna.

Med utgångspunkt i ovanstående beskrivningar undersöker denna artikel vilka språknormer som verbaliseras det vill säga uttrycks genom talat språk, och praktiseras, alltså uttrycks genom handlingar och interaktion, i en undervisningspraktik där eleverna ännu inte är funktionellt litterata. Analysen av språknormer baseras på Jørgensens (2008) beskrivning av fyra typer av språkligt beteende (se vidare avsnittet Språkideologier och språknormer).

\section{Syfte och frågeställningar}

Syftet med artikeln är att undersöka en sfi-lärares verbalt uttryckta och praktiserade språknormer för att bidra till förståelsen för förutsättningarna för transspråkande pedagogik inom undervisning för ännu inte funktionellt litterata vuxna andraspråksinlärare.

Frågeställningarna är:

1. Vilka språknormer verbaliseras läraren i sitt tal om undervisningen?

2. Vilka språknormer praktiserar läraren i samband med undervisningen?

3. Vad innebär dessa språknormer för förutsättningarna att utveckla en transspråkande pedagogik inom sfi-undervisning?

\section{Artikelns uppläggning}

Nedan belyses först sfi som utbildningsdomän. Därefter framläggs artikelns teoretiska utgångspunkter med fokus på språknormer, språkideologier och transspråkande, varefter material och metoder presenteras. Sedan följer resultatavsnittet där analysen av lärarens verbaliserade och praktiserade språknormer framläggs, och slutligen diskuteras det som framkommit av analysen. 


\section{Sfi som utbildningsdomän}

Sfi erbjuder utbildning i svenska till vuxna personer bosatta i Sverige vilka saknar grundläggande kunskap i språket. De elever som läser sfi utgör en heterogen grupp vad gäller tidigare erfarenheter av formell utbildning, yrkesarbete, nuvarande livssituation och planer för framtiden. Därför framhålls flexibilitet som en central aspekt i kursplanen för sfi (Skolverket 2019) och utbildningen är indelad i tre olika studievägar (1, 2 och 3) samt fyra olika kurser (A, B, C och D) för att uppnå en individualisering av utbildningen. Denna studie är förlagd till kurs A.

Tabell 1. Studievägar och kurser på sfi.

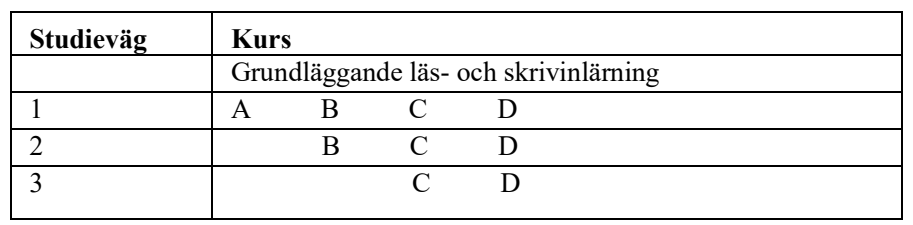

Studieväg 1 är avsedd för personer som har kort eller ingen tidigare erfarenhet av formell utbildning (Skolverket 2019). Studieväg 2 är inriktad mot personer vars skolgång är kortare än motsvarande svensk gymnasieskola. Studietakten är därmed långsammast på studieväg 1 och snabbast på studieväg 3. Studieväg 3 riktar sig till personer som har genomgått gymnasium och eventuellt även högskolestudier. Kurs A är vanligtvis den första kursen elever på studieväg 1 läser medan kurs B är den första kursen på studieväg 2 och kurs $C$ är den första kursen på studieväg 3 .

\section{Teoretiska utgångspunkter}

I följande avsnitt redogörs först för språkideologier och språknormer ur ett teoretiskt perspektiv och därefter fokuseras tidigare forskning om språkideologier och språknormer i språkligt heterogena utbildningskontexter. Efter detta belyses transspråkande som teori och pedagogik.

\section{Språkideologier och språknormer}

Språkideologier förstås i denna artikel som vardagliga och ofta normativa grundläggande uppfattningar om språk som reflekteras, skapas och återskapas $\mathrm{i}$ en process där hegemoniska maktförhållanden upprätthålls (Woolard \& Schieffelin 1994; Blommaert \& Verscheuren 1998: 25; Woolard 1998; Kroskrity 2006; Jonsson 2017). Ideologier kan beskrivas som diskurser kopplade till makt vilka människor möter i policydokument utfärdade av staten och i interaktion med personer knutna till olika institutioner (Woolard 1998: 7). Så småningom börjar människor uppfatta dessa ideologier som neutrala och universella sanningar (Ganuza \& Hedman 2017).

Medan språkideologier skapas och återskapas uppifrån, top down, består språknormer av implicita normativa uppfattningar om språk som skapas 
nerifrån, bottom up, genom interaktion i en specifik kontext (Bonacina-Pugh 2017: 8-9). Genom denna interaktion skapas alltså normer för vad som är acceptabelt eller inte $\mathrm{i}$ relation till lokalt skapade regler $\mathrm{i}$ ett visst specifikt sammanhang. Men samtidigt påverkas den specifika kontexten av språkliga händelser som har ägt rum på andra platser eller på samma plats vid andra tillfällen (Wortham \& Reyes 2015). Sambandet mellan språkideologier som skapas uppifrån och språknormer som skapas nerifrån kan undersökas genom det som Wortham \& Reyes kallar en discourse analysis beyond the speech event, det vill säga en diskursanalys som belyser språkliga drag både i den specifika språkhändelsen och samband mellan den och andra språkhändelser som sker i andra kontexter.

Begreppet språknorm används något olika av olika forskare. I min analys väljer jag att följa Jørgensen (2008) som menar att människors språkliga beteende kan indelas utifrån fyra olika språknormer:

\section{The monolingualism norm}

Persons with access to more than one language should be sure to master one of them before getting into contact with the other

\section{The double monolingualism norm}

Persons who command two languages will at any given time use one and only one language, and they use each of their languages in a way that does not in principle differ from the way monolinguals use the same language

The integrated bilingualism norm Persons who command two languages will employ their full linguistic competence in two different languages at any given time adjusted to the needs and the possibilities of the conversation, including the linguistic skills of the interlocutors

\section{The polylingualism norm}

Language users employ whatever linguistic features are at their disposal to achieve their communicative aims as best they can, regardless of how well they know the involved languages; this entails that the language users may know and use the fact that some of the features are perceived by some speakers as not belonging together. (Jørgensen 2008:163)

Enligt Jørgensen (2008: 168) är den enspråkiga normen, the monolingualism norm, nära förknippad med en uppfattning om ett nära samband mellan ett folk, en nation och ett språk. Denna norm hade inflytande långt in på nittonhundratalet och medförde bland annat att språkvetare varnade för att låta barn växa upp med två språk om inte särskilda villkor var uppfyllda. $\mathrm{Nu}$ har den dock, enligt Jørgensen, ersatts av den dubbelt enspråkiga normen, the double monolingualism norm, vilken är inflytelserik i många moderna samhällen (Blackledge 2008; Spindler-Møller \& Jørgensen 2009; Jonsson 2017), bland annat i utbildningskontexter (Jonsson 2013), där lärare bidrar till att upprätthålla denna norm (Musk 2010). Jonsson (2017) framhåller att det i 
enlighet med den dubbelt enspråkiga normen är korrekt att tala ett språk i taget medan transspråkande ses som fel eller avvikande.

Den integrerade den integrerade flerspråkiga normen, the integrated bilingualism norm, och den polyspråkliga normen, the polylingualism norm, är öppnare för flerspråkigt beteende än den enspråkiga och den dubbelt enspråkiga normen. Skillnaden mellan den integrerade flerspråkiga normen och den polyspråkliga normen ligger $\mathrm{i}$ att den förstnämnda utgår från att samtalsparterna endast använder de språk de behärskar. Talare som inte "kan" arabiska, engelska eller turkiska förutsätts inte använda dessa språk. Något sådant förbehåll finns inte inom den polyspråkliga normen, utan där öppnas upp för alla talare att använda ord och uttryck ur vilka språk som helst, oavsett vilka kunskaper de har i språket i fråga. Det innebär att den polyspråkliga normen öppnar för mer inkluderande språkpraktiker (Jonsson 2017).

\section{Språkideologier och språknormer i flerspråkiga utbildningskontexter}

Sedan 1980-talet har forskare (Cummins 1981; Grosjean 1982; Cummins 2000) motsatt sig den seglivade synen på flerspråkighet som ett problem som länge har varit dominerande $\mathrm{i}$ många utbildningskontexter. Forskare (Cummins 1981; 1986; Hornberger 2003) har också under lång tid genom sina studier lyft fram elevers flerspråkiga repertoarer som legitima och värdefulla resurser att använda i klassrummet. Även förståelsen av flerspråkiga individers språkliga system som en enhet snarare än separata delar har sedan länge lyfts fram, till exempel genom Cummins (1981) begrepp common underlying proficiency, gemensam underliggande förmåga, det vill säga en kunskapsbas som är överförbar mellan språk.

I en senare studie har Bonacina-Pugh (2017) undersökt hur nyanlända elever i förberedelseklass i en skola i Frankrike vet vilka språk som är legitima i klassrummet. Hennes kritiska perspektiv innebär ett fokus på sociala, ekonomiska och politiska faktorer som begränsar språkpraktiker och $\mathrm{i}$ enlighet med detta perspektiv är ett språk att betrakta som legitimt om det stöds av diskurser och ideologier som är dominerande $\mathrm{i}$ en vidare samhällskontext (Bonacina-Pugh 2017: 4) Hon kommer fram till att trots att andra språk än franska inte är legitimerade av språkpolicy och språkideologier som kännetecknas av ett top-down-perspektiv, ses de ändå som legitima i enlighet med den lokala praktiserade språkpolicyn som hon menar spelar en nyckelroll i legitimeringen av flerspråkiga språkpraktiker.

I svensk kontext har Ganuza och Hedman (2017) diskuterat begreppen translanguaging och pedagogical translanguaging inom modersmålsundervisning. De använder intervjuer med modersmålslärare samt klassrumsobservationer från lärarnas undervisning $i$ en analys av deras uttalade och praktiserade ideologier. Med utgångspunkt i analysen diskuterar Ganuza och Hedman (2017: 219) om begreppen transspråkande och pedagogiskt transspråkande är lämpliga begrepp för att beskriva de lingvistiska och pedagogiska praktikerna inom modersmålsundervisning med 
tanke på att dessa begrepp är förknippade med en specifik uppsättning teoretiska uppfattningar om språk och pedagogik. De fann att de kommunikativa praktikerna $\mathrm{i}$ de undersökta modersmålskontexterna präglades av enspråkig ideologi som stod i kontrast till uppfattningen om vad pedagogiskt transspråkande innebär. Vidare framhåller de att begreppet pedagogiskt transspråkande inte bör användas $\mathrm{i}$ beskrivningen av utbildningskontexter där lärare och elever deltar i flerspråkiga praktiker men inte reflekterar över dessa praktiker och inte har något medvetet mål när det gäller hur praktikerna ska leda till lärande. De menar nämligen att det i så fall finns en risk att begreppet förlorar sin inneboende kraft, vilket skulle medföra att forskare förlorar sin åtkomst till ett kraftfullt verktyg som kan användas för att beskriva en typ av flerspråkiga praktiker som enligt dem möjligen är ovanliga. De menar därför att begreppet pedagogiskt transspråkande enbart ska användas för sammanhang där flerspråkiga praktiker används på ett explicit och medvetet sätt och där de flerspråkiga praktiker som kan observeras i klassrummet är förenliga med de ideologier som verbaliseras och praktiseras av både lärare och elever i den kommunikativa praktiken (Ganuza \& Hedman 2017: 222).

\section{Transspråkande som teori och pedagogik}

Begreppet transspråkande är mångdimensionellt och används i olika betydelser. Mazak (2017: 5) anlägger fem olika perspektiv på begreppet, där transspråkande kan ses som
I. en språkideologi
II. en teori om två- och flerspråkighet
III. ett pedagogiskt förhållningssätt
IV. en form av praktik
V. en transformerande process

Eftersom denna artikel undersöker språknormer i en utbildningskontext är transspråkande som ett pedagogiskt förhållningssätt centralt. Dock blir även de övriga perspektiven viktiga eftersom de är sammanvävda och påverkar varandra.

Forskning om transspråkande är knuten till paradigmskiften inom språkvetenskaplig forskning som har medfört att utgångspunkterna $\mathrm{i}$ forskningen inte längre är homogenitet, stabilitet och åtskillnad mellan språk utan mobilitet, blandning, politisk dynamik och kontextbundenhet (Blommaert \& Rampton 2011: 3). Därmed har även ideologin som innebär en nation ett språk kommit att kritiseras för att leda till monolingvistiska språkideologier och en uppfattning om en two solitudes-föreställning om flerspråkighet. Begreppet two solitudes används av Cummins (2007) som benämning på den föreställning som förekommer inom tvåspråkiga undervisningsprogram om att elevernas förstaspråk och andraspråk ska vara 
strikt skilda från varandra. En sådant särskiljande innebär bland annat att lärarna inte bör blanda språken i undervisningen.

I enlighet med transspråkande som teori betraktas två- och flerspråkiga individers användning av varieteter, register eller språk som integrerad (García 2009; Canagarajah 2011). Detta innebär att flerspråkiga talare kan växla mellan språk och behandla de olika språk som ingår i deras repertoar som ett samordnat och sammansatt system. Transspråkande utmanar därmed en uppfattning om språk som separata enheter. Växlingen mellan språk sker intuitivt och förekommer naturligt i vardagslivet och därmed kan den, i likhet med andra förmågor, betraktas som möjlig att vidareutveckla genom utbildning (Jonsson 2017).

En annan aspekt av transspråkande som teori är att språk förstås som en aktivitet, språkande, languaging, snarare än som ett statiskt fenomen. Språk är således en pågående process vilken enbart existerar i form av språkande (García 2009). På så sätt förskjuts fokus från språk som avskilda enheter till språkande som ett konstant pågående aktivt meningsskapande

Transspråkande pedagogik avser i denna artikel det som García och Kano (2014: 261) beskriver som "en process genom vilken elever och lärare engagerar sig i komplexa, diskursiva praktiker som inkluderar alla elevers språkliga praktiker för att utveckla nya språkpraktiker och vidmakthålla gamla, kommunicera lämplig kunskap, och ge röst åt nya sociopolitiska realiteter genom att ifrågasätta språklig ojämlikhet" (översatt till svenska av Paulsrud m. fl. 2018: 13, kursivering i original.) Transspråkande är i enlighet med denna förståelse ett pedagogiskt förhållningssätt som innebär att elever, lärare och samhällen använder och vidmakthåller flerspråkiga personers repertoarer på ett sätt som kan medföra större engagemang i elevernas lärande och ökad social jämlikhet och rättvisa (García 2009; García \& Leiva 2014; Menken \& Garcia 2016: 8-9; Paulsrud m. fl. 2018: 13).

\section{Tidigare forskning om flerspråkiga utbildningskontexter}

I följande avsnitt presenteras först forskning om transspråkande i språkligt heterogena utbildningskontexter generellt, och därefter fokuseras forskning om transspråkande i sfi-undervisning specifikt.

\section{Forskning om lingvistiskt heterogena i utbildningskontexter}

Forskning om flerspråkiga utbildningskontexter på många olika platser på jorden har belyst den komplexitet och variation som kännetecknar elevers och lärares flerspråkiga praktiker och hur dessa bidrar till lärande i lingvistiskt heterogena klassrum (García \& Kleifgen 2010; Creese \& Blackledge 2011; Stille \& Cummins 2013; Reath Warren 2016; 2017; Ganuza \& Hedman 2017). Samtidigt uppvisar flerspråkiga klassrum på olika platser jorden runt också stora olikheter. De kan fördelas längs ett kontinuum där den ena slutpunkten utgörs av lingvistiskt symmetriska (Bonacina-Pugh 2013) klassrum där lärare och elever har samma språkliga repertoar, eller med andra 
ord talar samma språk. Detta gäller exempelvis inom modersmålsundervisning i Sverige. Den andra slutpunkten utgörs av lingvistiskt asymmetriska klassrum där lärare och elever har mycket olika språkliga repertoarer. Detta gäller exempelvis för sfi-klassrum. Majoriteten av studierna om flerspråkiga klassrum behandlar klassrum som i stor utsträckning är lingvistiskt symmetriska (Bonacina-Pugh 2013). Detta gäller även för studier som utgår från transspråkande som teori och som undersöker transspråkande pedagogik. Vidare behandlar majoriteten av forskningen undervisning från motsvarande svensk förskoleklass upp till årskurs 3 på gymnasiet, medan lite forskning finns om transspråkande i vuxenundervisning som inte är universitetsutbildning (Poza 2017: 115).

\section{Forskning om flerspråkiga praktiker inom sfi}

Forskning om läs- och skrivundervisning på grundläggande nivå har i stor utsträckning inriktats mot yngre barn medan forskning med fokus på vuxnas litteracitet ofta inriktas mot läsande och skrivande på en avancerad nivå (Wedin, Rosén \& Hennius 2018: 2). Till det fåtal studier som utförts om flerspråkiga praktiker inom sfi hör Roséns \& Bagga-Guptas (2015) undersökning. De studerar hur språkpolicy förhandlas fram på policynivå och i klassrumskontext inom sfi-utbildning. Författarna undersöker hur språklagens princip att svenska är huvudspråk i Sverige förvandlas och utmanas i interaktionen i sfi-klassrum. De konstaterar att en enspråkig norm är framträdande i det ena av de undersökta klassrummen medan en flerspråkig norm dominerar i det andra.

Även Wedin, Rosén \& Hennius (2018) har undersökt flerspråkiga praktiker inom sfi, närmare bestämt elevers användning av transspråkande inklusive multimodalitet i grundläggande skriftspråksundervisning. Studien utformades som ett aktionsforskningsprojekt där elever som läste kurs B och C på studieväg 1 på två olika skolor interagerade genom att blogga. I analysen av elevernas språkanvändning under arbete i smågrupp och helklass framkom att interaktionen innefattade språkutvecklande förhandling, omformulering och reparationer vilket även kännetecknades av transspråkande. Eleverna fick genom detta arbete ett visst mått av inflytande över det egna lärandet, även om det var läraren som utförde det direkta bloggandet. Forskarna menar att skriftspråksundervisning som syftar till att förbereda eleverna inför deltagandet i samhällslivet bör stödja deras nyttjande av olika språkliga resurser. Vidare bör undervisningen inte särskilja lärande från skriftanvändning som är kopplad till medborgarskap och vardagsliv.

\section{Material och insamlingsmetod}

Det empiriska material som artikeln baseras på skapades inom en mindre studie som var inriktad mot flerspråkiga och digitala skriftpraktiker inom grundläggande läs- och skrivundervisning inom sfi. Utifrån etnografisk metodologi utfördes klassrumsobservationer samt intervjuer med lärare och 
elever på två olika sfi-skolor. Det material som utforskas här består av de tre semistrukturerade intervjuer på totalt 176 minuter $(64,71$ och 41 minuter) som utfördes med en sfi-lärare samt klassrumsobservationer utförda under tio skoldagar i den klass hon undervisade.

Intervjuerna dokumenterades genom audioinspelning samt fältanteckningar som skrevs efter deras utförande. Klassrumsobservationerna dokumenterades med hjälp av audio- och videoinspelning samt fältanteckningar som skrevs under utförandet. Såväl vid intervjuerna som observationerna togs fotografier för att dokumentera texter, artefakter och miljöer.

\section{Etiska ställningstaganden}

I enlighet med Vetenskapsrådets (2017) etiska regler har deltagarnas integritet och behov tagits $\mathrm{i}$ beaktande vid utförandet av studien. Läraren och eleverna gavs muntlig och skriftlig information varefter de tillfrågades om och gav skriftligt samtycke att medverka. Den muntliga informationen till eleverna gavs på svenska, arabiska, somaliska och kurdiska. Den skriftliga informationen gavs på svenska. De informerades även om möjligheten att när som helst avbryta sitt deltagande. Forskningsmaterialet har förvarats så att endast forskaren haft tillgång till det och för att säkerställa deltagarnas anonymitet har namn på personer och platser bytts ut eller tagits bort när forskningsmaterial har presenterats eller publicerats.

\section{Informanterna och undervisningskontexten}

Den aktuella läraren, här benämnd Charlotte, har utbildning till och erfarenhet som förskollärare, speciallärare, grundskollärare och sfi-lärare. På sfi har hon arbetat i fem år och undervisar nu en grupp på 18 elever på kurs A på studieväg 1. Eleverna talar arabiska, dari, sorani, kurmanji, tigrinja, somaliska och thailändska. Klassen är heterogen när det gäller elevernas erfarenhet av formell undervisning och ungefär hälften av eleverna är funktionellt litterata på sitt förstaspråk eller ett annat språk. Enligt läraren har en del elever gått ett par år i skolan så att de kan läsa hjälpligt. En annan ganska stor grupp bland eleverna har gått ca åtta år i skolan men kan ändå inte läsa på grund av läsoch skrivsvårigheter och har mycket negativa erfarenheter av att gå i skolan. I klassen finns också elever som inte har gått i skolan alls och som över huvud taget inte kan läsa på något språk. Under klassrumsobservationerna kännetecknas undervisningen främst av helklassinteraktion. Vissa inslag finns även av enskilt arbete och par- eller gruppövningar.

\section{Analysmetoder}

Det första analyssteget bestod $i$ att intervjuerna transkriberades i enlighet med en modifierad version av en transkriptionsnyckel utformad av Poland (2004). Skriftspråksnormer har följts när det gäller interpunktion och huvudsakligen även vad gäller stavning. 


\section{Transkriptionsnyckel}

(...) Tre prickar inom parentes markerar en paus på en halv sekund till två sekunder.

(paus) Ordet paus inom parentes markerar en paus som är två sekunder eller längre.

(Suckar) Icke-lingvistisk information, till exempel att någon skrattar, suckar eller nyser, inom parentes.

Det BLIR så Versaler markerar att något uttalas med emfas.

"Men du vad menar hon, ja" Citattecken betecknar återgivet tal.

.... Fyra punkter anger att en del av interaktionen har uteslutits i intervjuutdraget.

Nästa analyssteg bestod i att med hjälp av fältanteckningar identifiera situationer $\mathrm{i}$ observationsmaterialet där läraren verbaliserade eller praktiserade språknormer. Videofilmssekvenser från de aktuella situationerna transkriberades därefter.

I analysen av intervju- och observationsmaterial gjorde jag även både en innehållsligt inriktad kategorisering med fokus på vad språkhändelsen handlar om och vilka språknormer som verbaliseras eller praktiseras i de språkliga händelserna och en diskursanalys inriktad på hur språknormerna konstrueras. Den innehållsligt inriktade kategoriseringen och analysen utgick dels från Jørgensens (2008) beskrivning av språknormer som kännetecknar människors användning av språk (se avsnittet Språkideologier och språknormer ovan), dels från ett antal sociolingvistiskt grundade frågor (Ivanič et al. 2009: 50 samt Norlund Shaswar 2014: 74). Dessa frågor riktade in sig på vem som initierade språkhändelsen och kontrollerade dess syfte, på vilken plats och när den ägde rum, vilken domän den hörde till, vilket ämnesinnehåll den hade, vilka som deltog och vilka identiteter och värderingar som aktualiserades i händelsen, vilka de lästa eller producerade texternas mottagare var samt vilka språk och teknologier som användes.

För att analysera konstruktionen av språknormer har jag tillämpat diskursanalys med fokus på utpekande språkliga drag, indexical signs, (Wortham \& Reyes 2015; Reath Warren 2017). De utpekande språkliga drag som har analyserats är personliga utpekande ord, det vill säga sådana som syftar på talaren eller personer som hen talar till eller om, till exempel vi, oss, dem, spatiala och temporala utpekande ord, till exempel här, där, hemma, då, förra veckan, och diskursiva utpekande ord, till exempel den lektionen, de eleverna.

Därutöver analyserar jag även återgivet tal, det vill säga att talaren återger något som sagts på en annan plats vid ett annat tillfälle, och expressiva utpekande ord och uttryck, evaluative indexicals. De senare utgörs av "any signs that associate people or objects with some recognizable social type and evaluate that type" (Wortham \& Reyes 2015: 52). Exempelvis kan 
användningen av uttrycket "de här konstiga översättningsgrejerna" visa att läraren har en negativ uppfattning om digitala översättningsverktyg och att hon därigenom positionerar sig genom att använda det uttrycket.

Analysen av dessa språkliga drag bidrar på olika sätt till ett synliggörande både av de språknormer som råder i den lokala kontexten i klassrummet där läraren befinner sig när språkhändelsen äger rum och av språknormer och språkideologier som råder bortom den omedelbara kontexten samt sambandet mellan det lokala och det som sker bortom det lokala (Wortham \& Reyes 2015: 40-41; Reath Warren 2017: 7). Ett fokus på dessa typer av uttryck i analysen gör det således möjligt att synliggöra hur lärarens språknormer är inbäddade i och skapade av social kontext. Analysen gör det också möjligt att synliggöra om och i så fall hur hon aktivt bidrar till att omskapa språknormer (Canagarajah, 2015; Canagarajah \& De Costa, 2015; Reath Warren 2017).

\section{Resultat: Analys av lärarens verbaliserade och praktiserade språknormer}

I resultatavsnittet analyseras konstruktionen av språknormer i intervju- och observationsmaterialet. Eftersom den språknorm som Jørgensen (2008: 163; 168) benämner den enspråkiga normen är förknippad med samband mellan ett folk, en nation och ett språk är den normen inte aktuell att undersöka i denna studie där fokus är inriktat mot en lärare som undervisar vuxna flerspråkiga elever. Därför består resultatavsnittet av analys av lärarens konstruktion av den dubbelt enspråkiga normen, den integrerade flerspråkiga normen och avslutningsvis den polyspråkliga normen.

\section{Den dubbelt enspråkiga normen}

Här återges analysen av konstruktionen av den dubbelt enspråkiga normen i intervju- och observationsmaterialet. Denna norm föreskriver att flerspråkiga ska använda ett av sina språk i taget (Jørgensen 2008).

Lärarens redogörelser innehåller flera olika argument för att eleverna inte bör använda andra språk än svenska för sin språkliga interaktion och produktion i klassrummet. I nedanstående intervjuutdrag synliggörs verbaliserande av den dubbelt enspråkiga normen genom argumentet att användningen av enbart svenska främjar förståelsen i klassrummet.

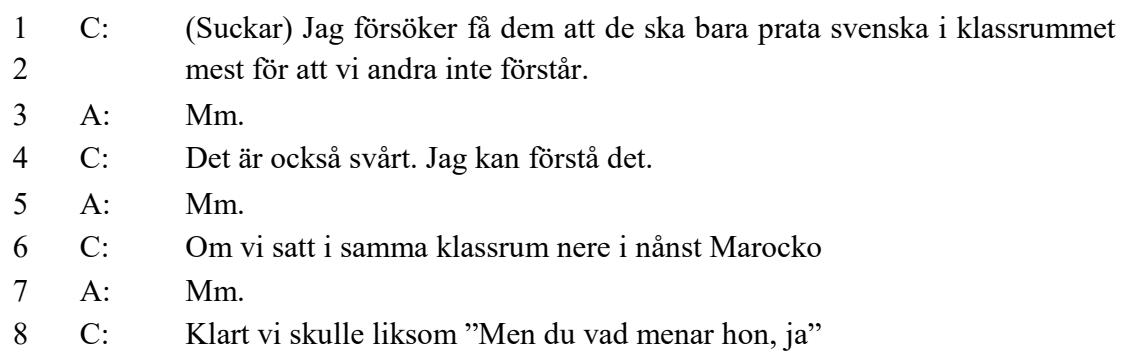


Förståelsen hos de personer som inte förstår det talade språket blir i utdraget ett argument för att enbart svenska ska talas i klassrummet, medan förståelsen hos de elever som talar det andra språket inte nämns.

Vidare visar de personliga utpekande pronomenen i intervjuutdraget att läraren först förhåller sig till eleverna som jag ställt mot dem, när det på rad 1 är hon som "försöker få dem att de ska bara prata svenska", men därefter, på rad 2, inkluderar läraren sig själv i elevgruppen som inte förstår dem som inte pratar svenska i "mest för att vi andra inte förstår." Läraren uttrycker alltså i detta utdrag å ena sidan att hon står utanför elevgruppen och försöker införliva en dubbelt enspråkig norm i klassrummet, medan hon därefter inkluderar sig själv i ett vi, tillsammans med elever som inte förstår de språk som talas.

Genom de spatialt utpekande orden i detta citat framkommer att den språkliga normen är knuten till den specifika rumsliga kontexten. Det är $i$ klassrummet, det vill säga på den lokala plats där undervisningen äger rum, som hon vill att eleverna bara ska tala svenska. Därefter säger läraren ( $\operatorname{rad} 4)$ att hon förstår att det är svårt, underförstått att det är svårt för eleverna, att prata svenska. På rad 6 och 8 föreställer hon sig sedan en annan rumslig kontext där hon och jag, forskaren som intervjuar henne och som också har svenska som förstaspråk, sitter i ett klassrum i Marocko där vi inte förstår språket. Läraren tänker sig här att rollerna skulle vara ombytta, så att hon och jag skulle vara elever och sitta i ett klassrum som andraspråksinlärare. Med utgångspunkt $\mathrm{i}$ denna föreställning om ombytta roller uttrycker hon förståelse för elevernas svårigheter med att enbart interagera på målspråket. I utdraget vacklar läraren alltså mellan en dubbelt enspråkig och förståelse för behovet av en integrerad flerspråkig norm.

Kopplingen mellan den dubbelt enspråkiga normen och klassrummet som rumslig kontext modifieras $i$ en av språkhändelserna under klassrumsobservationen. Där tydliggörs att utöver klassrummet som plats är även den pågående aktiviteten avgörande för lärarens konstruktion av språknormen. Språkhändelsen äger rum i inledningen av dagens första lektion och sammanfattas nedan:

Läraren sitter vid bordet framme vid tavlan och markerar i en pärm samtidigt som hon säger elevers namn "I, F, A, okej." Samtidigt som läraren fortsätter tala med klassen reser hon sig upp: "Förra veckan då var inte $\mathrm{S}$ här, inte $\mathrm{F}$ inte $\mathrm{R}$ inte M. Men det var bara två dagar. Men vi skrev en liten text, en text, förstår alla text" "Två manliga elever svarar "Ja". Ett par elever pratar med varandra på arabiska. Läraren hyssjar åt dem. Hon står upp framme vid lärarbordet och bläddrar i en hög med papper som hon har där. Hon håller upp två papper och säger "Nu har jag bara två. Jag måste gå och kopiera. Okej? En minut? NU kan ni prata. Nu går jag och kopierar." Hon tar sina nycklar och springer mot dörren. Samtidigt säger en manlig elev som är arabisktalande "Arabiska, svenska?" Läraren säger "Nu kan du prata arabiska, jag ska kopiera." Medan hon är ute pratar eleverna på olika språk med varandra. Arabiska, dari, kurdiska mm hörs. Efter två minuter kommer läraren in igen. 
Läraren betonar det första temporalt utpekande ordet $n u$ i meningen "NU kan ni prata. Nu går jag och kopierar." Detta tolkar jag som ett framhävande av kontrasten mot interaktionen strax innan, när hon hyssjade åt de elever som talade arabiska. Den manlige arabisktalande eleven ställer frågan "Arabiska, svenska?" och verkar därmed vilja ha ett förtydligande av vilket språk han får tala, alltså hur han ska tolka lärarens "NU kan ni prata". Genom användningen av pronomenet jag i "Nu går jag och kopierar" tydliggör läraren också att det är under hennes frånvaro det är tillåtet för eleverna att prata sina förstaspråk. Genom den ovan beskrivna interaktionen mellan läraren och eleverna konstruerar läraren en språknorm enligt vilken det är tillåtet för eleverna att tala andra språk än svenska i klassrummet när hon inte är där. Det är alltså inte rummet som är avgörande utan lärarens närvaro där, och därmed vilken aktivitet som pågår. Den dubbelt enspråkiga normen knyts därmed till lärarens närvaro i klassrummet.

Ett annat av lärarens argument för att eleverna enbart ska prata svenska under lektionerna är att lektionerna är den enda tiden då de talar svenska:

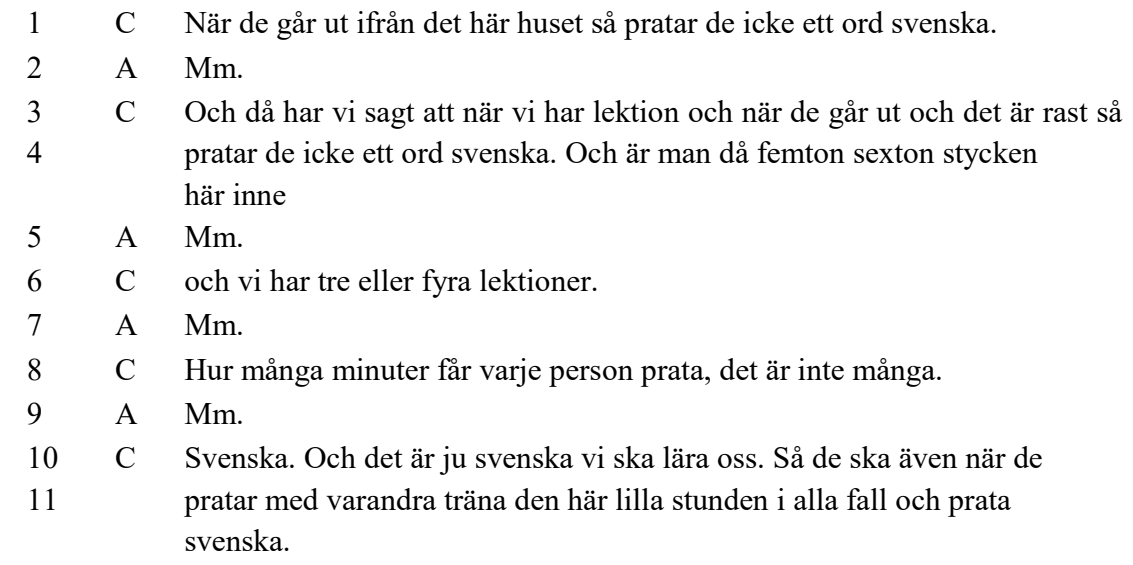

I intervjuutdraget ovan lyfter läraren fram att det är under lektionerna som eleverna ska prata svenska. Genom användningen av de utpekande personliga pronomenen konstruerar läraren den dubbelt enspråkiga normen genom att inkludera eleverna $\mathrm{i}$ ett $v i$ när hon säger "Och då har vi sagt att när vi har lektion" ( $\mathrm{rad} 3)$. Genom lärarens användning av temporalt utpekande ord (rad 10-11) konstrueras klassrummet som en specifik arena för en dubbelt enspråkig norm. På rad 10 börjar hon med att använda första person plural, $v i$, och alltså inkludera sig själv när hon hänvisar till dem som ska lära sig svenska, till att senare på samma rad använda tredje person plural, de. Hon växlar därmed från ett inifrån-perspektiv där hon identifierar sig med inlärarna, till ett utifrån-perspektiv där hon talar om dem. Genom att på rad 11 framställa lektionstiden som den här lilla stunden gör hon den knappa 
tiden till ett argument för en dubbelt enspråkig norm i enlighet med vilken svenskan ska separeras från andra delar av elevernas språkliga repertoarer.

Under klassrumsobservationen lägger jag dock märke till att eleverna väldigt ofta använder andra delar än svenska ur sin språkliga repertoar i sin interaktion med varandra. De talar bland annat arabiska, dari och somaliska, ofta med hög röst och tvärs över klassrummet, även medan läraren vänder sig till hela klassen i undervisning i form av helklassinteraktion. $\AA$ ena sidan uppmanar läraren ibland vid dessa tillfällen eleverna att tala svenska, men å andra sidan lämnar hon ofta deras interaktion på andra språk okommenterad. Trots elevernas praktiserade motstånd mot den dubbelt enspråkiga normen hör jag dock ingen elev verbalisera detta motstånd på något av de språk jag förstår (svenska, kurdiska, engelska).

\section{Digitala översättningsverktyg och den dubbelt enspråkiga normen}

I lärarens redogörelser finns en nära koppling mellan användning av digitala översättningsverktyg och konstruktionen av en dubbelt enspråkig norm. Hon uttrycker vid ett flertal tillfällen i intervjuerna en negativ syn på elevernas användning av digitala översättningsprogram på laptop eller mobiltelefon.

1 A Och de sitter eh en del sitter med datorn uppe ganska ofta.

2 C (Suckar) Ja en del sitter ju hela tiden. Då får man ju sluta med för de lyssnar ju

3 inte på mig utan de tror att "Om jag inte förstår ett ord då ska jag gå in och

4 kolla på Lexin eller på Google översätt eller nånting"

5 A Mm.

6 C Och det kan ju bli, då ser man (Skrattar) ser man på dem när de ser så här ut

$7 \quad$ "Vad fasen menar hon egentligen?"/

I utdraget ovan framhåller läraren först (rad 2-4) att de digitala översättningsverktygen medför att eleverna inte lyssnar på henne under lektionerna. Sedan (rad 6-7) framställer hon de översättningar eleverna gör av hennes tal under lektionerna som obegripliga för dem. Detta gör hon genom att föreställa sig vad eleverna tänker vid anblicken av översättningarna (i det återgivna talet på rad 6-7). Läraren ställer också (rad 2-4) den flerspråkiga strategin att slå upp ord i digitala översättningsprogram emot den enspråkigt svenska strategin att lyssna på läraren. Genom sin växling mellan pronomenen man $(\operatorname{rad} 2,6)$ och mig $(\operatorname{rad} 3)$ växlar läraren mellan att framställa sitt personliga ansvar för konstruktionen av den dubbelt enspråkiga språknormen som mindre genom man eller större genom mig.

Denna framställning av digitala översättningsverktyg som problematisk modifieras i intervjuutdraget nedan där läraren knyter den till undervisningsform. Vid helklassundervisning ska de lyssna på läraren och försöka förstå vad hon säger, men vid individuellt arbete får de använda översättningsverktygen. 
1 C Utan det är när jag pratar som de sitter och gör det och då då ska de lyssna

2 och försöka

5 A Mm.

6 C fnurra ut. Nä men jag tycker att de ska använda dem när vi har våra,

7 dels när vi har de lektioner som vi har och sen använda dem ja men på

8 avsatt tid faktiskt. (Hostar) Vi har ju ganska mycket tid som det är

9 individuellt arbete och DÅ kan de använda dem.

I nedanstående utdrag positionerar sig läraren i förhållande till kontexter utanför klassrummet när hon talar om elevernas användning av digitala översättningsverktyg. I utdraget använder hon uteslutande pronomen i första person singular för att hänvisa till sig själv: (rad 3: "Nej för att jag tycker", rad 3-4: "Vad jag är ute efter", rad 15: "berätta nånting för mig", rad 28-29: "då behöver du inte lyssna på mig"). Därmed konstruerar hon sig själv som ansvarig för den språknorm hon verbaliserar. I talet om eleverna växlar läraren mellan första person singular (jag på rad 4, 6, 11, 13, 18 och 32) andra person singular ( $d u$ på $\operatorname{rad} 28,31$ och $d i g$ på rad 9) och tredje person plural (de på rad 3, 6, 7, 15 17, 18, 26 och 32).

1 A Men men det här att de använder datorer det tycker du inte är så bra att de 2 sitter och jobb... att de tar det, sitta och titta på...

3 C Nej för att jag tycker att det kan de, alltså på den här nivån ska de inte göra

4 det. Vad jag är ute efter det är om jag inte förstår

5 A Mm.

$6 \quad \mathrm{C}$ då ska jag då ska jag tala om det. För när de träffar en granne och de inte

7 förstår så kan de ju inte ta upp datorn.

8 A Mm.

9 C Utan träna dig på att säga, att blotta dig

10 A Mm.

11 C att säga "Jag förstår inte."

12 A Just det.

$13 \mathrm{C}$ Och då måste jag förklara runt ikring.

14 A Mm.

15 C Likadant som de ska lära sig att när de ska berätta nånting för mig och inte har ordet

16 A Mm.

17 C De har inte ordet koppel till exempel. De vill berätta att de har köpt ett nytt

18 koppel till sin hund. Nu har de inte hund (skrattar) då men du förstår. Och

19 jag kan inte ordet koppel.

20 A Mm.

21 C I stället för att bli tyst (...) säga då "Ja du vet ett sånt här rep som man sätter

22 runt halsen på hunden.

23 A Mm.

24 C Att prata runt.

25 A Just det. 
26 C Det är det jag är ute efter att de ska lära sig.

27 A Mm.

28 C Och då är det helt vansinnigt att sitta med och översätta hela tiden för då

29 behöver du ju inte lyssna på mig.

30 A Näe.

31 C Du behöver aldrig liksom "Va fasen menar människan?" Så ner med locken bara så här. Sen när de sitter och jobbar själv, var så god, gör det.

Genom pronomenväxlingen varierar läraren mellan att placera sig i elevernas position (jag), tilltala eleverna $(d u$, dig) och att omtala eleverna $(d e)$ i verbaliseringen av den dubbelt enspråkiga normen. Hon varierar därmed gällande vilken närhet till eleverna hon uttrycker, och därmed även, skulle man kunna tänka sig, gällande hur stor förståelse för deras situation hon känner.

Vidare utvecklar läraren i citatet ovan sin syn på vad eleverna ska göra när de söker efter ett ord i enspråkigt svenska temporala och spatiala kontexter utanför klassrummet, "när de träffar en granne". Lärarens konstruktion av en dubbelt enspråkig norm i klassrumskontexten sker alltså i relation till vad hon ser som elevernas behov av att lära sig strategier för enspråkiga sammanhang utanför klassrummet. En sådan strategi är enligt läraren att säga till samtalspartnern "Jag förstår inte."

I intervjuutdraget ovan används det diskursivt utpekande uttrycket "på den här nivån" ( $\operatorname{rad} 3)$ som argument för att eleverna på A-kursen i stället för den flerspråkiga strategin att använda digitala översättningsprogram ska välja den enspråkiga strategin att lyssna på läraren. Som syns i utdraget nedan återkommer läraren till det diskursivt utpekande uttrycket den här nivån (rad 20 nedan) vilket ställs mot ett annat diskursivt utpekande uttryck: de andra kurserna $(\operatorname{rad} 2)$. I detta sammanhang uttrycker läraren förståelse för elevers användning av den där översättningen ( $\mathrm{rad} 1$ ) när de läser svårare texter, har kommit längre i andraspråksutvecklingen och "har en kontext" (rad 3) runt texten.

1 C Jag tycker ju inte att det är något bra att sitta på den där översättningen. Inte

2 i det här inte i den här (...) Jag förstår på de andra kurserna om du sitter och

3 läser en en en svår text och de kan det mesta och de har en kontext men de

4 hakar upp sig på ETT ord.

5 A $\mathrm{Mm}$.

$6 \quad$ C Då förstår jag att de sitter med det.

7 A $\mathrm{Mm}$.

8 C Men de här alltså de hakar upp sig på kan haka upp sig på så dumma ord som

9 inte ens har någon betydelse för kontexten.

10 A Aa.

11 C Eh

12 A Så de får inget sammanhang. 
13 C Nej de får inget sammanhang så det det ger ingenting plus att de

14 använder sig av de här konstiga översättningsgrejerna och det blir ju

15 bara, man ser ju ungefär (?) tänker "Vad MENAR människan?"

16 A Mm.

17 C Ehm och (...) och vi läser aldrig sådana texter som att de behöver en

18 översätta själva texten.

19 A Mm.

20 C Men i på den HÄR nivån så är det (...) den mänskliga kommunikationen

21 A Mm.

23 C som är nummer ett.

I intervjuutdraget ovan konstrueras alltså användningen av översättningsverktyg som knuten till elevernas nivå av läsförståelse. Verktygen är enligt läraren lämpliga för elever som läser mer avancerade texter och som känner till sammanhanget runt dem. Elever som inte har kommit så långt $\mathrm{i}$ läsutvecklingen riskerar däremot, enligt läraren, att fokusera på ord som inte är betydelsefulla för kontexten ( $\operatorname{rad} 8-9$ ) och därför är denna flerspråkiga strategi olämplig för dem menar hon.

Det förekommer även att läraren i verbaliseringen av den dubbelt enspråkiga normen hänvisar till att elevernas nyttjande av digitala verktyg sker "på deras eget språk". Detta sker i följande intervjuutdrag

1 C Nej men de använder de där apparaterna men det är dessvärre på deras eget språk

2 A Mm.

Det negativt laddade värderande adverbet "dessvärre" (rad 1 ovan) visar att hon ser användningen av elevernas "eget språk" som något negativt. Även i utdraget nedan ger läraren uttryck för en negativ syn på elevernas modersmål.

1 C Men att tro att de ska kunna sitta själva och slå på nå lexikon då har de inte

2 de har inte språkkunskaperna vare sig (...) i svenska eller kanske ibland på sitt modersmål

3 A Näe.

4 C för det är ju också en grej

5 A $\mathrm{Mm}$

6 C som vi har pratat om

7 A Mm. Mm.

8 C att det är inte alltid superutvecklat

Enligt läraren har eleverna "inte alltid språkkunskaperna" ( $\operatorname{rad} 2)$, vare sig på "sitt modersmål" (rad 2) eller på svenska för att själva kunna använda översättningsverktyg. Deras modersmål beskriver läraren också som "inte 
alltid superutvecklat”. Läraren konstruerar alltså här en bristdiskurs när hon talar om elevernas språkliga repertoar.

Sammantaget uttrycker läraren i sina redogörelser att elevernas användning av digitala översättningsverktyg under vissa förhållanden är problematisk. Hennes redogörelse för användningen av verktygen är knuten till konstruktionen av en verbaliserad dubbelt enspråkig norm. Dock ser och hör jag under nästan varje observerad lektion hur eleverna kontinuerligt ärarens instruktioner genom att använda översättningsprogram på datorer eller mobiltelefoner, även under helklassinteraktion.

\section{Den integrerade flerspråkiga normen}

Det finns enbart ett fåtal exempel i intervju- och i observationsmaterialet på att läraren verbaliserar en integrerad flerspråkig norm. Jag finner inga exempel i intervju- eller observationsmaterialet på att läraren i interaktionen med eleverna använder engelska, som är ett språk hon behärskar. Däremot finns exempel på att hon initierar språkhändelser där eleverna får använda språk de behärskar. I intervjuutdraget nedan finns ett exempel på att läraren verbaliserar den integrerade flerspråkiga normen.

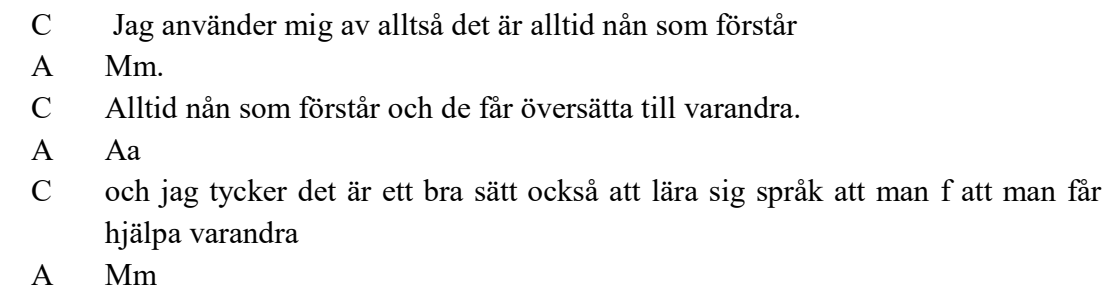

Konstruktionen av en integrerad flerspråkig norm sker här genom det expressivt laddade uttrycket "ett bra sätt" som kopplar positivt laddade värderingar till en praktik där elever använder flera delar av sin språkliga repertoar i klassrummet, och där de "får hjälpa varandra" ( $\operatorname{rad} 5-6)$.

I observationsmaterialet finns ett exempel på en språkhändelse där läraren i didaktiskt syfte, $\mathrm{i}$ undervisning om personliga pronomen, uppmanar eleverna att använda delar av sina språkliga repertoarer som hon själv inte behärskar. Lärarens handlingar kan därmed kategoriseras som praktisering av en integrerad flerspråkig norm. Språkhändelsen är 40 minuter lång. Nedan ges en beskrivning av den med nedslag i dess inledning, mitt och slut, i syfte att visa hur den initieras, vilket slag av utmaningar läraren ställs inför och hur hon bemöter dem. Beskrivningen nedan är gjord med hjälp av fältanteckningar och videofilmer.

Det är ca 45 minuter in på dagens första lektion. Läraren står i den främre delen av klassrummet. På väggen finns en kombinerad whiteboard- och interaktiv tavla. Eleverna sitter i sina bänkar och tittar på den.

Läraren: $\mathrm{Nu}$ vill jag att ni lyssnar noga. $\mathrm{Nu}$ ska vi prata och när vi pratar, jag vet 
att, jag vet inte på arabiska men jag vet på kurdiska, där säger man inte han och hon (pekar på elever), eller hur?

Arabisktalande elev: Ja, ja

Läraren: utan man säger samma. Är det likadant på arabiska?

Arabisktalande elev: Nej det är samma svenska, olika. Inti och anta.

Läraren: Okej. (Läraren skriver i det övre vänstra hörnet av whiteboardtavlan:

"Jag" Hon vänder sig mot klassen) Jag på svenska. (Hon vänder sig mot tavlan och skriver "ana") ana på arabiska.

Kurdisktalande elev: Az

Läraren: kurdiska

Kurdisktalande elev: Az

Läraren: as (Läraren skriver "as" på whiteboardtavlan) Eh somaliska

Somalisktalande elev: Aniga

(Läraren skriver "annika")

Somalisktalande elev: Aniga

Läraren: naniga (Läraren suddar) Jag hade trott att ni säger annika.

Somalisktalande elev: Aniga.

(Läraren suddar och skriver "aniga")

Läraren: Första gången jag träffade en somalisk kvinna och hon pratade om aniga, då trodde jag att det, för att det finns ett kvinnonamn som heter Annika i

Sverige och jag tänkte 'Vem är Annika'. (Läraren pekar på en daritalande elev.)

Daritalande elev: Mar.

Läraren: Man?

Daritalande elev: Mar.

Läraren: Mar

(Två daritalande elever pratar med varandra på dari.)

Daritalande elev1: Mar.

(Läraren skriver "mar")

Läraren: Okej.

Daritalande elev2: Nej man man

Läraren: Men han säger man, okej, de är lite osams där.

(Bredvid "mar" på tavlan lägger läraren till ett snedstreck och "man" så att det står "mar/man".

(Två daritalande elever pratar med varandra på dari.

Läraren: Det kan vara olika i dialekt, olika dialekt.

(Läraren tittar på klassen)

Läraren: Okej, alla förstår 'jag'

Läraren fortsätter fråga eleverna vad pronomenen heter och skriver dem på tavlan tills kolumnerna i bild 1 nedan bildas. 


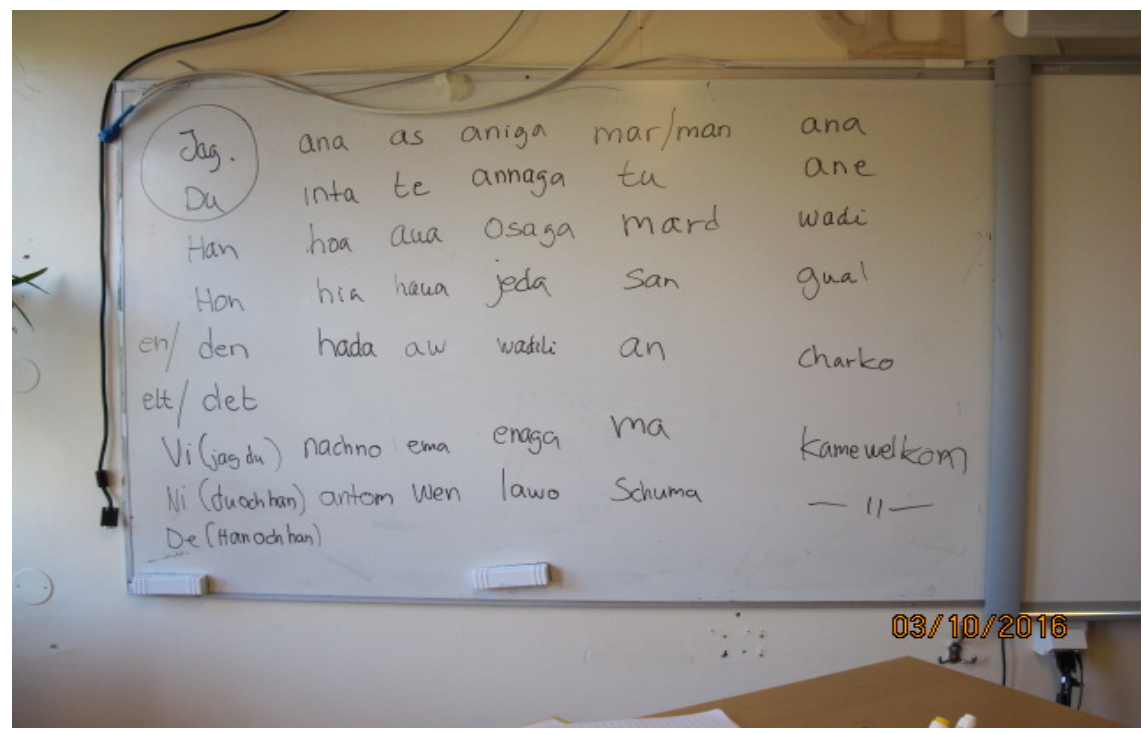

Bild 1: Pronomen på whiteboardtavlan

När de kommer till "den" inträffar följande:

Läraren: Okej, hada. (Läraren håller upp tavelpennan och går fram till whiteboarden och pekar bredvid "hada") Kurdiska.

Kurdisktalande elev: Kalama

(Läraren skriver "kalama" Hon går sedan fram till en somalisktalande elev.)

Somalisktalande elev: Alim. Alim. Alim.

Forskaren: Charlotte, det betyder penna.

(Läraren tittar på forskaren och sedan på eleven och pekar på penna hon håller i)

Nej nej nej det är penna. Nej det är fel.

Lärarens syfte med denna språkhändelse skulle kunna vara att dels underlätta elevernas inlärning av svenska personliga pronomen genom att knyta dem till pronomen i de språk de behärskar, dels att stärka deras identitet genom att lyfta in deras språkliga repertoarer i undervisningen.

Det finns stora skillnader mellan svenskans och de övriga inblandade språkens skriftsystem. Läraren ber inte elever komma fram och skriva pronomenen på tavlan med de skriftsystem och den ortografi de använder för sina språk utan skriver själv med latinska bokstäver utifrån hur hon via sin hörsel uppfattar att orden uttalas. Det är möjligt att elevernas inlärning av de svenska pronomenen hade underlättats än mer om eleverna själva hade fått komma fram till tavlan och skriva pronomenen.

En annan aspekt av lärarens nyttjande av språkliga repertoarer är att hon genom att låta dem uppmärksammas och synliggöras visar att de är värdefulla. 


\title{
Praktisering av den polyspråkliga normen
}

I detta första avsnitt fokuseras hur den polyspråkliga normen praktiseras och i det nästkommande avsnittet undersöks hur den verbaliseras.

Charlotte praktiserar ibland den polyspråkliga normen i samband med sin undervisning. Detta sker exempelvis genom att hon använder ord från arabiska för att markera att en lektion är slut: "hörrni, vi säger så här, vi säger bes $^{l}$ " (Fältanteckningar). Under en annan språkhändelse (fältanteckningar), när det endast är åtta elever närvarande, sitter läraren tillsammans med eleverna runt ett bord och samtalar om bostäder och hur de bor. Qais har dari som förstaspråk. När turen kommer till honom berättar han att han bara har ett rum. Charlotte svarar då "Men inshallah ${ }^{2}$ får du en annan lägenhet”.

Ett annat exempel på när läraren praktiserar den polyspråkliga normen i interaktionen med eleverna under en lektion följer nedan. I denna språkhändelse visar Alia, en kvinnlig elev från Afghanistan, bilder från sin dotters bröllop. Alia sitter på en stol i den främre delen av klassrummet och bilderna projiceras på den interaktiva tavlan bakom henne.

\begin{abstract}
Läraren pekar på en karaff med röd vätska på bilden och säger "Vad är det där?" Läraren gapar med munnen och gör en förskräckt min. Alia ler. En annan elev säger "Sherbet chie ${ }^{3}$ ?" Läraren säger med hög röst "Haram ${ }^{4}$ haram haram" Mums mums mums. Dricker ni vin på bröllop?" Alia skrattar och tittar på sina klasskamrater. Alia säger "Juice juice juice" Qais, en manlig afghansk elev säger "Nej inte vin, saft saft saft".
\end{abstract}

Både Alia och flera andra elever skrattar när läraren använder ordet "haram" från arabiska. I kombination med användningen av ordet använder läraren även ansiktsuttryck och höjd röst för att ge ett intryck av förskräckelse. Lärarens konstruktion av en polyspråklig norm kan här sägas kännetecknas av en lekfullhet.

\section{Verbalisering av den polyspråkliga normen}

I den första intervjun, utförd efter fem dagars klassrumsobservation, frågade jag läraren om hennes användning av ord från elevernas språk i undervisningen:

1 A Aa. (...) Ehm. Jo jag tänkte på det här med språk. (...) Eh när de (...) Jag

2 hörde att du ibland använder arabiska ord så här "Jalla" och lite sådant.

3 C Ja.

4 A Hur (skrattar lite) hur tänker du kring det, alltså var kommer det ifrån liksom?

$5 \quad$ (skrattar lite)

6 C Nej men det är för jag tycker "Jalla" är ett så himla bra ord.

1 det räcker

2 förhoppningsvis

3 Vad heter saft?

4 förbjudet 


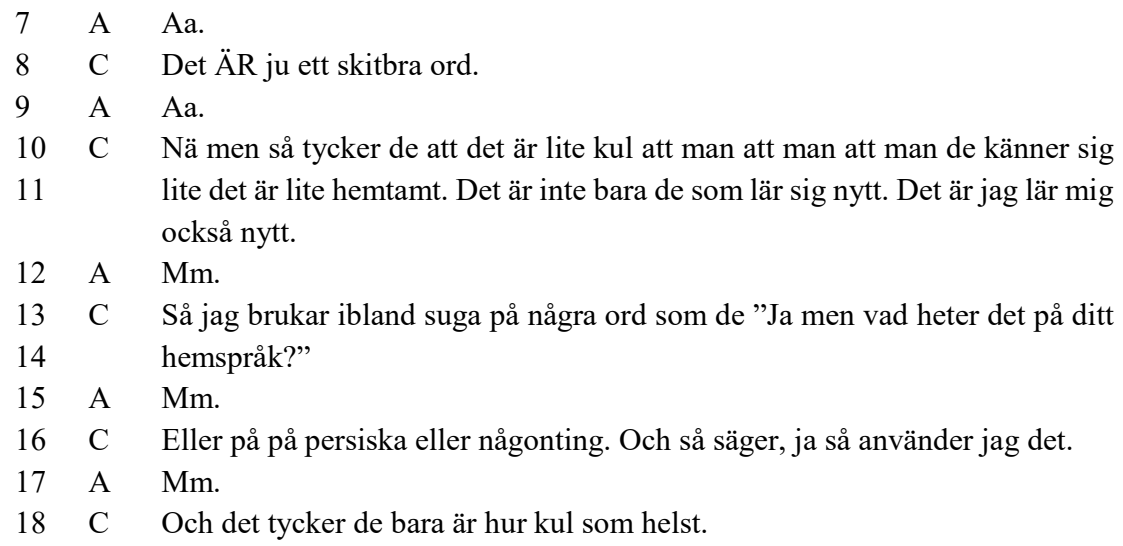

Läraren verbaliserar positiva värderingar knutna till användningen av orden. Ett syfte med användningen av ord från elevernas språk är att detta gör att det blir "lite hemtamt" ( $\operatorname{rad} 11)$ för eleverna. Läraren uttrycker också ( $\operatorname{rad} 11$ ovan) att hon genom att använda ord från elevernas språk får lära sig något nytt. I den praktik hon beskriver blir lärarrollen därmed något mer lik elevrollen.

I utdraget nedan uttrycker läraren att hon har börjat lära sig lite arabiska genom sin interaktion med eleverna. Läraren beskriver här sin reaktion på upptäckten att hon kunde känna igen arabiska ord när hon såg en intervju med en arabisktalande man på teve:

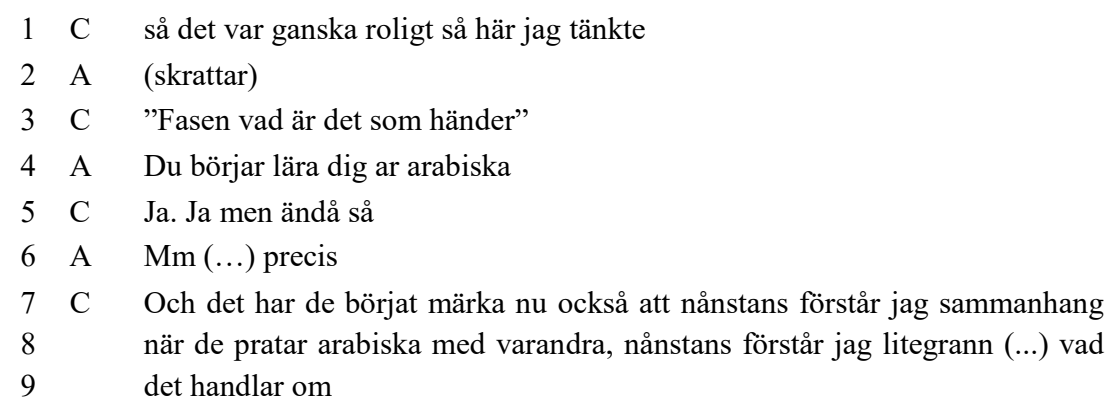

På rad 3 uttrycker läraren genom det återgivna talet den förvåning hon kände vid insikten att hon känner igen arabiska ord. Denna utveckling av hennes språkliga repertoar framställs även som glädjande när hon på rad 1 säger att hon uppfattade detta som "ganska roligt". På rad 7-9 framgår att hon inte bara känner igen ord utan även förstår sammanhang när eleverna talar med varandra. 


\section{Sammanfattning: Lärarens konstruktion av språknormer}

I redogörelserna i intervjumaterialet får den dubbelt enspråkiga normen stort utrymme medan den integrerade flerspråkiga normen och den polyspråkliga normen verbaliseras mer sparsamt. Läraren framhåller att det finns en överenskommelse mellan henne och eleverna om att de ska tala svenska i klassrummet och hon uppmanar dem under lektionerna att tala svenska med varandra. Men hon verbaliserar samtidigt en viss öppenhet gentemot den integrerade flerspråkiga normen genom att medge att den dubbelt enspråkiga normen kan vara svår för eleverna att efterleva. Dessutom modifieras verbaliseringen av den dubbelt enspråkiga normen genom att den bland annat knyts till undervisningsform. Detta blir synligt i talet om elevernas användning av digitala översättningsverktyg. Verbalisering av den dubbelt enspråkiga normen sker vid beskrivningen av elevernas användning av verktygen som problematisk under helklassundervisning medan en integrerad flerspråkig norm verbaliseras genom den positiva framställningen av användningen av verktygen i individuell undervisning.

Elevernas läsförståelseförmåga är en annan faktor som lyfts fram som avgörande i verbaliseringen av språknormer. Användning av digitala översättningsverktyg framställs som lämplig för elever som har en mer utvecklad läsförståelse och därmed verbaliseras en öppning för den integrerade flerspråkiga normen på andra sfi-kurser än A-kursen.

I intervjuerna finns exempel på ett bristperspektiv på elevernas språk samtidigt som det även finns exempel på uttryck för en syn på en vidgad språklig repertoar som något positivt. Läraren uttrycker exempelvis att det är "kul" när hon använder ord från de språk som eleverna talar. Vidare ges utrymme åt elevernas språkliga repertoarer i undervisningen genom nedteckning på whiteboardtavlan av pronomen ur deras repertoarer.

Aspekterna tid och plats är betydelsefulla för konstruktion av språknormer i materialet. I såväl den verbaliserade som den praktiserade konstruktionen av språknormer lyfts klassrummet fram som en arena där eleverna ska tala svenska. Den dubbelt enspråkiga normen modifieras dock genom att den knyts till lärarens närvaro under lektionstid. Under rasterna eller under lärarens frånvaro konstrueras klassrummet som öppet för elevernas hela språkliga repertoarer.

Läraren har formellt sett genom sin lärarroll kontrollen över användningen av språk i klassrummet. Dock visar både intervju- och observationsmaterial att denna kontroll ständigt ifrågasätts i elevernas praktiker. Detta innebär att läraren och eleverna deltar i en ständigt pågående men implicit förhandling om vilka språknormer som gäller.

\section{Diskussion}

Sammantaget visar studien att även om transspråkande praktiker förekommer i de undersökta nedslagen ur lärarens undervisning är det är tveksamt om det utifrån dessa nedslag är rättvisande att benämna de pedagogiska praktikerna 
transspråkande pedagogik. För det första har läraren inte formulerat något medvetet beslut om att inkludera elevernas hela språkliga repertoarer eller flexibla språkanvändning i sin undervisning (Ganuza \& Hedman 2017). För det andra växlar hon mellan att konstruera å ena sidan den dubbelt enspråkiga normen och å andra sidan den integrerade flerspråkiga och den polyspråkliga normen. Denna växling skulle kunna beskrivas som att det finns en variation när det gäller vilka språknormer läraren utgår från i sin undervisning. Ett skäl till att denna variation kan vara spänningen mellan å ena sidan ett starkt stöd för flerspråkighet i gällande styrdokument (Skolverket 2012; Skolverket 2019) och språklagen (Kulturdepartementet 2009) och å andra sidan en dominans av enspråkiga normer i svenska utbildningskontexter (Hyltenstam \& Milani 2012; Rosén 2017; Wedin, Rosén \& Hennius 2018).

Dock är det möjligt att vända på perspektivet och förstå förekomsten av alla tre språknormerna som en potential för utvecklingen av en transspråkande pedagogik inom sfi-undervisningen. Detta kan tyckas gå emot vad som har beskrivits som kärnan i en transspråkande pedagogik, nämligen integreringen av elevernas hela språkliga repertoar i undervisningen (Pauslrud et al. 2017: 11). Det skulle emellertid kunna framhållas att integreringen av repertoarerna inte kan vara ett självändamål inom sfi-undervisning eller annan andraspråksundervisning. Olika språknormer kan behöva praktiseras i olika undervisningssituationer bland annat beroende på undervisningsformen och syftet med det aktuella undervisningsmomentet. Exempelvis kan den integrerade flerspråkiga och den polyspråkliga normen vara mest lämpliga $\mathrm{i}$ en uppgift med fokus på förståelse av ett innehåll där elever på valfritt språk diskuterar innebörden i en skriven text. Därefter kan de, i en uppgift där fokus ligger på språklig form, i enlighet med en dubbelt enspråkig norm producera en egen text på svenska om samma innehåll.

I det undersökta materialet finns vissa uttryck för en medvetenhet om den hierarkiska relationen mellan lärare och elever. Läraren ger uttryck för att vara medveten om elevernas relativa underläge när hon genom användning av ord ur deras språkliga repertoarer konstruerar ett rollbyte där hon symboliskt intar elevrollen. Denna medvetenhet har likheter med inriktningen mot strävan efter social rättvisa inom transspråkandeforskning (García 2009; Poza 2017). Inom sfi-undervisning skulle en utveckling av undervisningen som är grundad $i$ en strävan efter social rättvisa även kunna innebära att deltagarna i grundläggande skriftspråksundervisning ges inflytande över vilket språk texter ska läsas och skrivas på samt i enlighet med vilka språknormer undervisningen ska utföras (Wedin, Rosén \& Hennius 2018).

Det bristperspektiv på elevernas språk som det finns exempel på i intervjumaterialet står i motsatsställning till förståelsen av andraspråksinlärares språkliga repertoarer som värdefull som är framträdande inom transspråkande (Paulsrud et al. 2017). Vikten av ett resursperspektiv på sfielevers språkkunskaper har framhållits bland annat av Franker (2011), Norlund Shaswar (2014) och Wedin, Rosén och Hennius (2018). Ett sätt att 
synliggöra elevernas språkliga repertoarer som resurser för lärande är att belysa deras skriftanvändning på olika språk i olika situationer i vardagslivet (Norlund Shaswar 2012; 2014). Skriftanvändning i vardagslivet utanför utbildningsdomäner är ofta osynlig på så sätt att den inte uppfattas som läsande och skrivande. Det kan till exempel handla om att läsa busstidtabellen, träna på körkortsteori eller att skriva sms till vänner. Sådan skriftanvändning kan lärare synliggöra exempelvis genom att be eleverna använda mobiltelefoner eller surfplattor till att fotografera situationer $\mathrm{i}$ vardagslivet där de använder skrift.

Den förekommande verbaliseringen och praktiseringen av en integrerad flerspråkig eller polyspråklig norm i de undersökta intervjuerna och observationerna förefaller dels syfta till att stärka en social relation mellan läraren och eleverna, dels ha ett didaktiskt syfte. Nyttjandet av elevernas språkliga repertoarer i undervisningen kan bidra till att bekräfta elevernas identitet och fungera som ett stöd för deras skrift- och andraspråksutveckling (Paulsrud et al. 2017; Stille \& Cummins 2013).

Vad gäller förutsättningarna för att utveckla en transspråkande pedagogik inom sfi-undervisning på studieväg 1 förefaller det dock finnas flera betydande hinder. Lärarna på denna studieväg ansvarar för undervisningen av vuxna elever som ska utveckla svenska på grundläggande nivå och bli funktionellt litterata. Eleverna ska kunna använda sina nya språkkunskaper i svenska till att delta aktivt i många olika situationer i sina vardagsliv, samhällsliv, arbetsliv och i eventuella fortsatta studier (Skolverket 2019). Sfilärare har i uppgift att erbjuda en god undervisning till elever med olika språkliga repertoarer, livserfarenheter, livssituationer och mål för framtiden (Norlund Shaswar 2014). Att sfi-klassrum är lingvistiskt asymmetriska är vanligt. I den undersökta klassen talas vissa språk av många elever men inget språk utöver svenska talas av alla. Sfi-lärares språkliga repertoar är vanligen olik elevernas. Det kontinuerliga intaget av elever på sfi medför dessutom att sammansättningen av språk i gruppen hela tiden varierar.

Fortsatt forskning behövs därför om användningen av en transspråkande pedagogik i sfi-undervisning (Bonacina-Pugh 2013). Brännande frågor berör lärares medvetandegörande av och reflektion över de egna språknormerna, utformandet av en undervisning som motverkar social orättvisa, där språknormer används medvetet och undervisningen kännetecknas inte bara av enspråkiga utan även av flerspråkiga normer. Därmed kan det bli möjligt att nyttja alla elevers språkliga repertoarer i den grundläggande skriftspråksundervisningen på studieväg 1 , också när variationen mellan elevernas repertoarer är stor.

Även om det är angeläget att forskare fortsätter bidra till utformandet av en transspråkande pedagogik för sfi kommer de dock inte att kunna erbjuda lärarna några färdiga eller allmängiltiga didaktiska lösningar. Utformningen av transspråkande pedagogik är komplex och måste ske i relation till just de specifika utbildningskontexter där lärare och elever befinner sig, de 
undervisningsmoment de arbetar med och de språkliga repertoarer de har tillgång till just där och då (Stille \& Cummins 2013; Blommaert \& Rampton 2011). Därför behövs inte bara forskning utan även erfarna och kloka sfilärares djupa insikter om elevernas hela språkliga repertoarer och dessa repertoarers potential för den aktuella undervisningssituationen.

\section{Referenser}

Blackledge, Adrian (2008), "Language ecology and language ideology", i Angela Creese, Peter Martin \& Nancy Hornberger (red.) Encyclopedia of Language and Education. Vol. 9: Ecology of language, New York: Springer, s. 27-40.

Blommaert, Jan \& Rampton, Ben (2011), "Language and superdiversity", Diversities 13(2): 1-19.

Blommaert, Jan \& Verschueren, Jef (1998), Debating Diversity: Analysing the discourse of tolerance. London: Routledge.

Bonacina-Pugh, Florence (2013), "Multilingual Label Quests: A Practice for the 'Asymmetrical' Multilingual Classroom', Linguistics and Education 24 (2): 142-164. http://dx.doi.org/10.1016/j.linged.2012.12.006.

Bonacina-Pugh, Florence (2017), "Legitimizing multilingual practices in the classroom: the role of the "practiced language policy", International Journal of Bilingual Education and Bilingualism, doi: 10.1080/13670050.2017.1372359.

Canagarajah, Suresh (2011), "Codemeshing in academic writing: Identifying teachable strategies of translanguaging", The Modern Language Journal. 95(3), 401-417. DOI: 10.11 11/J.1540-4781.201.

Canagarajah, Suresh (2015), "Shuttling between scales in the workplace: Reexamining policies and pedagogies for migrant professionals", Linguistics and Education, 34: 47-57. doi:10.1016/j.linged. 2015.08.002.

Canagarajah, Suresh \& De Costa, Peter (2015), "Introduction: Scales analysis and its uses and prospects in educational linguistics", Linguistics and Education, 34: 1-10. doi:10.1016/j.linged.2015.09.001.

Creese, Angela \& Blackledge, Adrian (2011), "Separate and flexible bilingualism in complementary schools: Multiple language practices in interrelationship", Journal of Pragmatics, 43: 1196-1208. doi:10. 1016/j.pragma.2010.10.006.

Cummins, Jim (1981), Bilingualism and Minority Language Children. Toronto, Ont.: Ontario Institute for Studies in Education.

Cummins, Jim (1986), "Empowering minority students: A framework for intervention", Harvard Educational Review, 56(1): 18-36. doi: 10.17763/haer.56.1.b327234461607787.

Cummins, Jim (2000), Language, Power and Pedagogy: Bilingual Children in the Crossfire. Clevedon: Multilingual Matters.

Cummins, Jim (2007), Rethinking monolingual instructional strategies in multilingual classrooms, Canadian Journal of Applied Linguistics 10 (2): 221-240. 
Fejes, Andreas (2019), Redo för komvux? Hur förbereder ämneslärarprogrammen och yrkeslärarprogrammen studenter för arbete $i$ kommunal vuxenutbildning? Linköping: Linköpings universitet.

Franker, Qarin (2011), Litteracitet och visuella texter. Studier om lärare och kortutbildade deltagare i sfi, Stockholm: Stockholms universitet. (Diss.).

Ganuza, Natalia \& Hedman, Christina (2017), "Ideology versus practice. Is there a space for pedagogical translanguaging in mother tongue instruction?" i BethAnne Paulsrud, Jenny Rosén, Boglárka Straszer \& Åsa Wedin (red.), New Perspectives on Translanguaging and Education. Bristol: Multilingual Matters.

García, Ofelia (2009), Bilingual education in the 21st Century: A global perspective. Malden, MA: Wiley/Blackwell.

García, Ofelia \& Kano, Naomi (2014), "Translanguaging as process and pedagogy: Developing the English writing of Japanese students in the US" $\mathrm{i}$ Jean Conteh and Gabriela Meier (red.) The Multilingual Turn in Language Education: Opportunities and Challenges, Bristol: Maltilingual Matters, s. 292-299.

García, Ofelia \& Kleifgen, Jo Anne (2010), Educating emergent bilinguals: Policies, programs and practices for English language learners, New York, NY: Teacher's College Press.

García, Ofelia \& Leiva, Camila (2014), "Theorizing and enacting translanguagin for social justice", i Adrian Blackledge, Adrian \& Angela Creese (red.), Heteroglossia as Practice and Pedagogy, Dordrecth: Springer, s. 199216.

García, Ofelia\& Li Wei (2014), Translanguaging: Language, Bilingualism and Education. New York: Palgrave Macmillan.

Grosjean, François (1982), Life with Two Languages: An introduction to bilingualism. Cambridge, Massacusetts and London, England: Harvard University Press.

Gustavsson, Hans-Olof (2007), "Utan bok är det ingen riktig undervisning". En studie av skolkulturella referensramar i sfi. Stockholm: Lärarhögskolan i Stockholm/Stockholms universitet. (Diss).

Hornberger, Nancy H. (red.) (2003), Continua of Biliteracy: An Ecological Framework for Educational Policy, Research and Practive in Multilingual Settings. Clevedon: Multilingual Matters.

Hyltenstam, Kenneth \& Milani, Tommaso (2012), "Flerspråkighetens sociopolitiska och sociokulturella ramar", i Kenneth Hyltenstam, Monica Axelsson \& Inger Lindberg, (red.), Flerspråkighet: En forskningsöversikt, Stockholm: Vetenskapsrådet, s. 17-152.

Ivanič, Roz et al. (2009), Improving Learning in College. Rethinking literacies across the curriculum. London \& New York: Routledge.

Jonsson, Carla (2013), "Translanguaging and multilingual literacies: diary-based case studies of adolescents in an international school", International Journal of the Sociology of Language 2013 (224), 85-117. doi 10.1515/ijsl-2013-0057.

Jonsson, Carla (2017), "Translanguaging and ideology: Moving away from a monolingual norm”, i BethAnne Paulsrud, Jenny Rosén, Boklárka Straszer 
\& Åsa Wedin (red.), New perspectives on translanguaging and education. Bristol: Multilingual Matters, s. 20-37.

Jørgensen, J. Normann (2008), "Polylingual Languaging Around and Among Children and Adolescents", International Journal of Multilingualism, 5(3): 161-176, doi:10.1080/1479071080238756.

Kulturdepartementet (2009), Språklag 2009:600. https://www.riksdagen.se/sv/ dokument-lagar/dokument/svensk-forfattningssamling/spraklag2009600_sfs-2009-600 (hämtad 2020-07-31).

Kroskrity, Paul V. (2006), "Language ideologies", i Alessandro Duranti. (red.) $A$ companion to linguistic anthropology (s. 496-517). Malden, MA: Blackwell.

Lundgren, Berit, (2005), Skolan i livet - Livet i skolan. Några illitterata invandrarkvinnor lär sig att tala, läsa och skriva på svenska som andraspråk. Umeå: Umeå universitet. (Diss).

Lundgren, Berit \& Rosén, Jenny (2017), 15 års forskning om sfi-En överblick. Stockholm: Ifous/Academedia.

Mazak, Catherine M. (2017), "Theorizing translanguaging practices in higher education", i, Catherine M. Mazak \& Kevin S. Carroll (red.), Translanguaging in higher education. Bristol: Multilingual Matters.

Menken, Kate \& García, Ofelia (2016), "Language policy in classrooms and schools" i McCarty, Teresa, (red.) Encyclopedia of Language and Education, Volume 1: Language Policy and Political Issues in Education (3 uppl.) s. 211-225.

Musk, Nigel (2010), "Code-switching and code-mixing in Welsh bilinguals' talk: confirming or refuting the maintenance of language boundaries?", Language, Culture and Curriculum, 23 (3), 179-197, doi: 10.1080/07908318.2010.515993.

Norlund Shaswar, Annika 2012, "Att se det osynliga. Forskning om skriftbruk i vardagsliv och klassrum bland kurdiska SFI-studerande", i Ann-Catrine Edlund (red.), Att läsa och att skriva. Två vågor av vardagligt skriftbruk $i$ Norden 1800-2000. Umeå: Umeå universitet \& Kungliga Skytteanska Samfundet, 221-234.

Norlund Shaswar, Annika (2014), Skriftbruk i vardagsliv och i sfi-utbildning En studie av fem kurdiska sfi-studerandes skriftbrukshistoria och skriftpraktiker. Umeå: Umeå universitet. (Diss.).

Paulsrud, Bethanne, Rosén, Jenny, Straszer, Boglárka \& Wedin, Åsa (2017), "Perspectives on Translanguaging in Education", i BethAnne Paulsrud, Jenny Rosén, Boglárka Straszer \& Åsa Wedin, Å (red.), New Perspectives on Translanguaging and Education. Multilingual Matters, s. 10-19.

Paulsrud, Bethanne, Rosén, Jenny, Straszer, Boglárka \& Wedin, Åsa (red.) (2018), Introduktion, i Transspråkande $i$ svenska utbildningssammanhang. Lund: Studentlitteratur.

Poland, Blake D. (2004), "Transcription Quality", i James A. Holstein, \& Jaber F. Gubrium (red.), Inside Interviewing. New Lenses, New Concerns. Thousand Oaks : Sage, 267-287. 
Poza, Luis (2017), "Translanguaging: Definitions, Implications and Further Needs in Burgeoning Inquiry", Berkeley Review of Education, 6(2). doi 10.5070/B86110060.

Reath Warren, Anne (2016), "Multilingual study guidance in the Swedish compulsory school and the development of multilingual literacies. Nordand, 11: 115-142.

Reath Warren, Anne (2017), "Monoglossic echoes in multilingual spaces: language narratives from a Vietnamese community language school in Australia", Current Issues in Language Planning, doi: 10.1080/14664208.2017.1337831.

Rosén, Jenny, (2017), "Spaces of Translanguaging in Swedish Education Policy", i BethAnne Paulsrud, Jenny Rosén, Boglárka Straszer \& Åsa Wedin (red.), New Perspectives on Translanguaging and Education. Multilingual Matters, s. 38-55.

Rosén, Jenny \& Bagga-Gupta, Sangeeta (2015), ”Prata svenska, vi är i Sverige [Talk Swedish, we are in Sweden!]: A study of practiced language policy in adult language learning", Linguistics and Eucation 31: 59-73. http://dx.doi.org/10.1016/j.linged.2015.05.003.

Skolverket (2012), SKOLFS 2012:101, Läroplan för vuxenutbildningen, file://C:/Users/ananor98/Downloads/L_roplan\%20f_r\%20vuxenutbildni ngen\%20(1).pdf (hämtat 2020-07-31).

Skolverket (2019), Kursplan för kommunal vuxenutbildning i svenska för invandrare.

https://www.skolverket.se/undervisning/vuxenutbildningen/komvuxsvenska-for-invandrare-sfi/laroplan-for-vux-och-kursplan-for-svenskafor-invandrare-sfi/kursplan-for-svenska-for-invandrare-sfi (hämtat 202001-31).

Spindler-Møller, J. \& Jørgensen, N. (2009), "From language to languaging: changing relations between humans and linguistic features", Acta Linguistica Hafniensia, 41(1): 143-166, DOI: 10.1080/037404609033 64185.

Stille, Saskia, \& Cummins, Jim (2013), "Foundation for learning: Engaging plurilingual students' linguistic repertoires in the elementary classroom", TESOL Quarterly, 47: 630-638. doi:10.1002/tesq.116.

Vetenskapsrådet (2017), God forskningssed. Stockholm: Vetenskapsrådet.

Wedin, Åsa Rosén, Jenny \& Hennius, Samira (2018), "Transspråkande modalitet i grundläggande skriftspråksundervisning inom sfi”, Pedagogisk Forskning $i$ Sverige 23(1-2), 15-38. doi.org/10.1080/0090988 2.2014.911942.

Woolard, Kathryn Ann (1998), "Introduction: Language ideology as a field of inquiry", i Bambi B. Schieffelin, Kathryn Ann Woolard \& Paul V. Kroskrity (red.), Language Ideologies. Practice and Theory), s. 3-50.

Woolard, Kathryn Ann \& Schieffelin, Bambi B. (1994), "Language ideology", Annual Review of Anthropology, 23: 55-82.

Wortham, Stanton \& Reyes, Angela (2015), Discourse Analysis Beyond the Speech Event. London: Routledge. 